\title{
Analysis of the Effect of Attitude toward Environment, Perceived Control Behavior and Ecological Packaging on Green Purchase Intention on Packaging Drinking Water (AMDK) Brand Cleo Eco Shape
}

\author{
Ahmadian Hafiz and Dudi Permana
}

\section{ABSTRACT}

This study examines the impact of Attitude toward Environment, Perceive Control Behavior and Ecological Packaging on green purchase intention of Cleo Eco Shape Bottled Drinking Water (AMDK). The population used is all Indonesian citizens who have not bought Cleo Ecoshape brand bottled water products. The sample used was 120 respondents. PLS is used to analyze research data. The results of this study indicate Attitude toward Environment, Perceive Control Behavior and Ecological Packaging have a positive and significant effect on Purchase Intention.

Keywords: Attitude toward Environment, Perceive Control Behaviour, Ecological Packaging, Green Purchase Intention.

Published Online: January 18, 2021

ISSN: 2507-1076

DOI: $10.24018 /$ ejbmr.2021.6.1.689

Ahmadian Hafiz

Master of Management, Universitas Mercu Buana Jakarta, Indonesia.

(e-mail: hafiz.ahmadian ${ }^{\circledR}$ gmail.com) Dudi Permana*

Master of Management, Universitas Mercu Buana Jakarta, Indonesia.

*Corresponding Author

\section{INTRODUCTION}

Plastic as pollution has become a phenomenon that has not been resolved until recently. One of the implementations of plastic is its use as bottled drinking water or bottled drinking water technology (AMDK). AMDK answers the difficulties experienced by humans by providing convenience and practicality in meeting drinking water needs.

AMDK is a solution for everyone so that sales are growing every year.

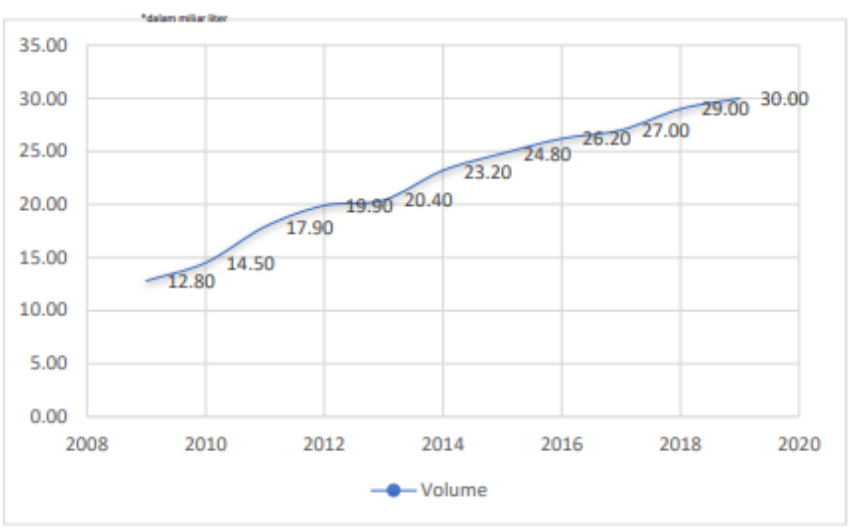

Fig. 1. Sales Volume of Bottled Water in Indonesia. Source: Ministry of Industry, 2019 (processed).

Industry players are currently increasing production, quality, and technology so as to produce environmentally friendly packaging with the aim of meeting bottled drinking water needs and reducing waste caused by plastics used as packaging. One of the bottled drinking water companies contributing to drinking water demand in Indonesia is the Cleo brand, namely PT. Sariguna Primatirta.

Thanks to his efforts, the Cleo bottled water brand was able to achieve sales growth of $31 \%$ in 2019. This growth was due to the high public interest in buying the Cleo brand with eco-friendly Eco Shape packaging.

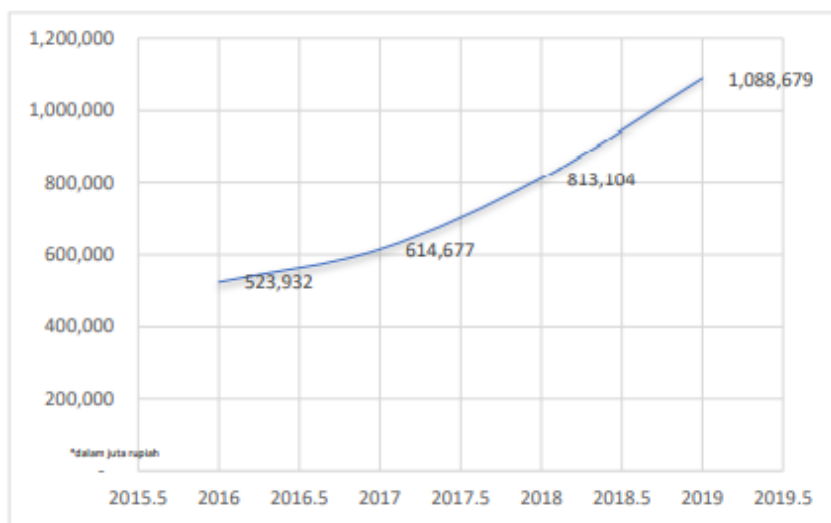

Fig. 2. Sales of PT. Sariguna Primatirta.

Source: (Financial Reports | Tanobel Food, no date).

From the picture above, it is known that consumers' green purchase intention for Cleo brand bottled water is very good. This indicates that company management must look for factors that affect consumer green purchase intention so that it can maintain the growth achieved by Cleo brand bottled water. 


\section{LITERATURE REVIEW}

Attitude toward environment describes the concern of producers to the environment so that it affects consumers' psychology so that it has an impact on the interest in buying a product [1]. With environmentally friendly production, people are interested in buying products [2].

Huang and Ge [3] argue that attitudes, perceived behavior, cognitive status, product perceptions and monetary incentive policy measures have a significant impact on consumer intentions. The intention that a person feels to do something is influenced by controlled attitudes and behavior [4].

Packaging on a product describes a visual and information element to attract consumers to buy a green package of the product. Then, the knowledge of green motivated consumers to choose green product packaging [5]. Shrestha [6] argues that marketing with the theme of green product and packaging plays an important role in encouraging purchase intention of a product.

Based on the literature above, a research framework is prepared that shows the relationship between variables.

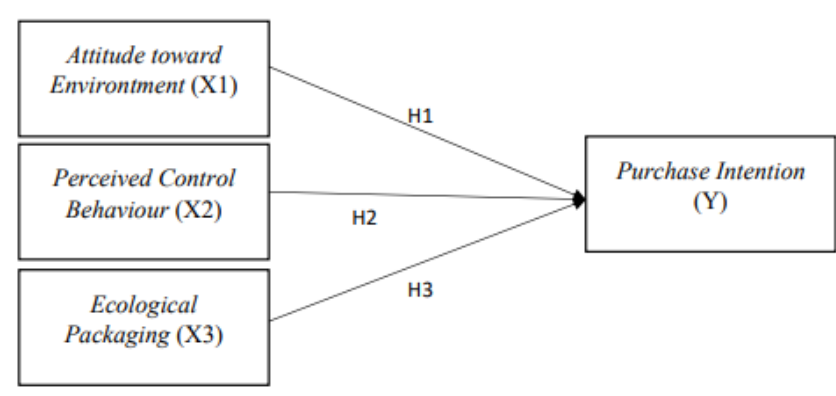

Fig. 3. Framework.

\section{RESEARCH METHODOLOGY}

Based on the research design, this research is included in conclusive research. The population tested was all Indonesian citizens who had not purchased Cleo Ecoshape brand bottled water products. The sample calculation uses the formula proposed by Hair et al. [7] so that 120 respondents were obtained. The data analysis technique used to analyze the effect of independent variables on the dependent variable is Structural Equation Modeling (SEM) with SmartPLS 3.0 software.

\section{RESEARCH RESULTS AND DISCUSSION}

Descriptive statistics on the research variables are presented in Table I.

The mean value for Attitude toward Environment's responses ranged from 3.85 to 4.08. The lowest average value is on the ATE3 indicator, so it is known that there are still some respondents who give disagreeing answers.

The average score for Ecological Packaging's answers ranged from 3.85 to 3.94 . The lowest average value is on the EP1 indicator, so it is known that there are still some respondents who give disagreement answers.
TABLE I. DESCRIPTIVE RESEARCH VARIABLES

\begin{tabular}{cccc}
\multicolumn{4}{c}{ TABLE I. DESCRIPTIVE RESEARCH } \\
\hline Variable & Indicator & Mean & Std. Dev \\
\hline \multirow{2}{*}{ Attitude toward } & ATE1 & 3.95 & 0.80 \\
Environment & ATE2 & 4.08 & 0.80 \\
& ATE3 & 3.85 & 0.82 \\
Ecological Packaging & EP1 & 3.85 & 0.74 \\
& EP2 & 3.94 & 0.70 \\
Perceived & EP3 & 3.88 & 0.81 \\
Behavioural Control & PBC1 & 4.07 & 0.78 \\
& PBC2 & 4.06 & 0.77 \\
Purchase Intention & PI1 & 4.22 & 0.75 \\
& PI2 & 3.79 & 0.77 \\
& PI3 & 3.52 & 0.90 \\
& PI4 & 3.82 & 0.87 \\
\hline
\end{tabular}

The average value of the Perceived Behavioral Control answers ranged from 4.06 to 4.07 . The lowest average value is on the PBC2 indicator, so it is known that there are still some respondents who give disagreement answers.

The average value of Purchase Intention answers ranged from 3.52 to 4.22 . The lowest average value is on the PI3 indicator, so it is known that there are still some respondents who give disagreement answers.

The assessment of the significance between variables was carried out by using the bootstrapping procedure. Through this procedure it is known the significance of the hypothesis by analyzing the T-Statistics value and the parameter coefficient value.

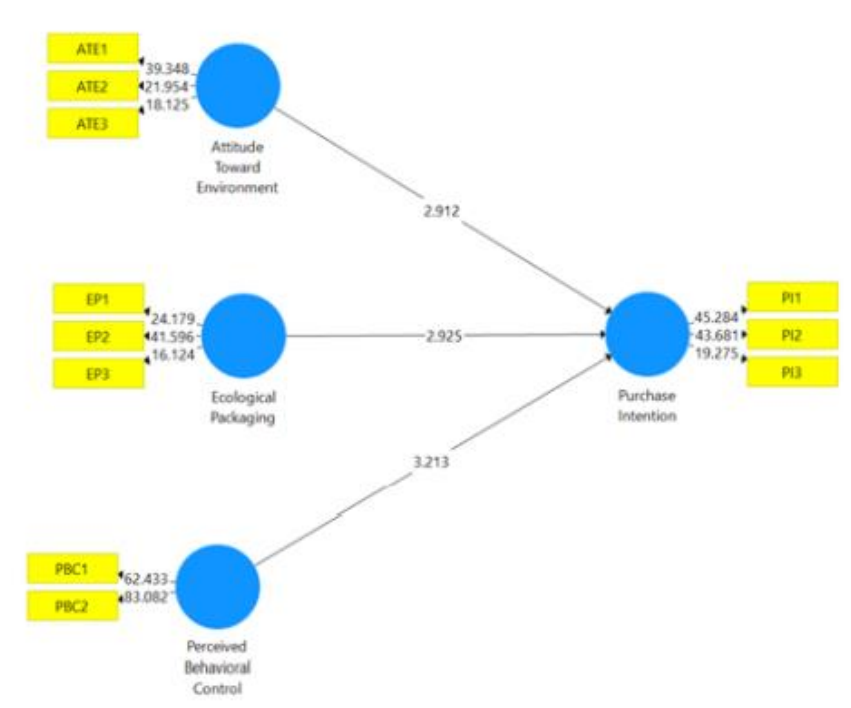

Fig. 4. Bootstrapping Results.

TABLE II: HYPOTHESIS TESTING RESULTS

\begin{tabular}{cccc}
\hline Construct & $\begin{array}{c}\text { Original } \\
\text { Sample }\end{array}$ & T-Statistics & Information \\
\hline $\begin{array}{c}\text { Attitude Toward } \\
\text { Environment }->\end{array}$ & 0.33 & 2.91 & $\begin{array}{c}\text { Positive, } \\
\text { significant }\end{array}$ \\
$\begin{array}{c}\text { Purchase Intention } \\
\text { Ecological Packaging } \\
->\text { Purchase Intention }\end{array}$ & 0.35 & 2.92 & $\begin{array}{c}\text { Positive, } \\
\text { significant }\end{array}$ \\
$\begin{array}{c}\text { Perceived Behavioral } \\
\text { Control -> Purchase } \\
\text { Intention }\end{array}$ & 0.24 & 3.21 & $\begin{array}{c}\text { Positive, } \\
\text { significant }\end{array}$ \\
\hline
\end{tabular}

Attitude Toward Environment has a significant positive effect on Purchase Intention. The value of t-statistics on this variable is 2.91 which is greater than t table 1.96 , meaning that respondents who have an environmentally friendly attitude will have a positive attitude towards ecological products and of course will participate in activities that 
provide protection to the environment. A positive attitude towards pro-environmental behavior will influence one's behavior to be more concerned about the environment and have an interest in buying environmentally friendly products. This becomes important in order to reduce the negative impact of environmental damage so as to create a sustainable environment.

Ecological Packaging has a significant positive effect on Purchase Intention. The t-statistics value of this variable is 2.92 which is greater than the t-table of 1.96 , meaning that the respondents already understand and understand the importance of applying ecological packaging. This is due to consumer awareness to maintain and pay attention to environmental sustainability. The use of ecological packaging is considered by consumers to help contribute to reducing the amount of waste in the environment illustrating behaviors such as recycling, choosing environmentally friendly packaging, minimizing waste, ethical disposal of non-biodegradable materials, and environmental awareness in purchasing decisions.

Perceived Behavioral Control has a significant positive effect on Purchase Intention. The value of t-statistics on this variable is 3.21 which is greater than t table 1.96, which means that respondents have a belief that there are supporting factors that are based on experience about information on the Cleo Ecoshape brand bottled water and create perceived behavioral control so that they have the intention to buy the product.

\section{CONCLUSIONS}

The results showed that Attitude Toward Environment, Ecological Packaging, and Perceived Behavioral Control had a significant positive effect on Purchase Intention.

Suggestions for Cleo Ecoshape brand bottled drinking water can sustainably develop packaging design technology where $100 \%$ recycled plastic or use plastics that are biodegradable. To improve the brand image, it is hoped that the company can increase its promotion with green advertising which informs that it uses $30 \%$ plastic compared to its kind and is $100 \%$ recyclable, so that information reaches consumers and creates a pro image for the environment.

As part of the socialization of environmentally friendly products, the company increases the intensity of its CSR (Corporate Social Responsibility) events to provide knowledge to consumers regarding the impact of plastic on the environment as well as the good and positive things of Cleo Ecoshape brand bottled water for life and the environment so that they are more preferred and confident to consume bottled water the Ecoshape Cleo brand that is pro on the environment.

\section{REFERENCES}

[1] Limbu, Y., Marco W., and Dale L. (2012). Consumers' perceptions of online ethics and its effects on satisfaction and loyalty. Journal of Research in Interactive Marketing, 5(1), 71-89.

[2] Yadav, R., and Pathak G. (2016). Determinants of Consumers Green Purchase Behavior in a Developing Nation: Applying and Extending the Theory of Planned Behavior. Ecological Economics, 134, 114122 .
[3] Huang, X and Jianping Ge. (2019). Electric vehicle development in Beijing: An analysis of consumer purchase intention. Journal of Cleaner Production, 216, 361-372.

[4] Nguyen, S. H., Dang, A. K., Vu, G. T., Nguyen, C. T., Le, T. H. T., Truong, N. T., and Ho, R. C. M. (2019). Lack of knowledge about sexually transmitted diseases (STDs): Implications for STDs prevention and care among dermatology patients in an urban city in Vietnam. International Journal of Environmental Research and Public Health, 16(6):1-15.

[5] Rajendran, S. and Wahab, S. N. (2017) 'Purchasing Intention towards Green Packaged Products: An Exploratory Study among Malaysian Consumers, 3rd International Conference on Advanced Research in Business and Social Sciences 2017 29th to 30th March, 2017, (March), 347-355.

[6] Shrestha, S. (2018) 'Analysis of Green Marketing Tools towards Consumer Purchase Intention in Kathmandu', Journal of Business and Social Sciences Research, 1(1), p. 37. doi: 10.3126/jbssr.v1i1.20948.

[7] Hair, J. F., Black, W. C., Babin, B. J. \& Anderson, R. E. 2010. Multivariate Data Analysis: A Global Perspective, New Jersey, Pearson Prentice Hall. 